Zenovii-Mykhaylo Zadorozhnyi,

Dr.Sc., Professor, West Ukrainian National University, Ukraine

iD ORCID ID, 0000-0002-2857-8504

email: zadoroznuy.zenoviy@gmail.com

Iryna Ometsinska,

Ph.D., Associate Professor, West Ukrainian National University, Ukraine

(iD ORCID ID, 0000-0001-6000-6904

email: irinaomec@ukr.net

Volodymyr Muravskyi,

Dr.Sc., Associate Professor, West Ukrainian National University, Ukraine

iD ORCID ID, 0000-0002-6423-9059

email: vavanm2@gmail.com

Correspondence author: vavanm2@gmail.com

\title{
DETERMINANTS OF FIRM'S INNOVATION: INCREASING THE TRANSPARENCY OF FINANCIAL STATEMENTS
}

Abstract. In terms of economic globalization and digitalization, the enterprise's financial reporting is a communication channel for transferring accounting information to stakeholders. The full and effective perception of user credentials is threatened by communication barriers that could lead to erroneous management decisions. Thus, it is necessary to improve financial reporting through feedback mechanisms to minimize the negative impact of communication threats to the accounting system. The purpose of this article is to identify basic communication of financial reporting, their minimization through ensuring the transparency of accounting information and calculation of analytical indicators. The article highlights the basic communication barriers to the perception of accounting information, which include unclear financial reporting indicators due to different interpretations of accounting concepts; the inadequate level of knowledge of the subjects of the communication process (communicator and recipient); the inaccuracy of information due to intentional or unintentional actions; lack of clarity in accounting regulations on the interpretation and structure of individual objects of accounting; information oversaturation; availability of non-target communications; availability of informal communications; inefficiency of the communication channel. The influence of communication threats to the accounting system on the example of forming the Ukrainian form of financial reporting Balance (Financial Statement) is substantiated. It is proposed to transform the form of financial statements Balance Sheet (Financial Statement) in Ukraine by separating two sections in assets "Non-current assets» and "Current assets») and three in liabilities ("Equity», "Long-term liabilities» and "Current liabilities») to optimize the analysis of the financial condition, which will contribute to the effective perception of accounting and analytical data by stakeholders. The criterion of minimizing the impact of communication risks should be used to transform other forms of financial and integrated reporting. The proposals could be useful in reformatting financial reporting forms in other countries to ensure transparency and maximize the perception of accounting information.

Keywords: financial statements, communication barriers, communication links, information users, transparency of financial statements, balance sheet (statement of financial position), liquidity ratios.

Introduction. Accounting is the main information base for enterprise management, its activity planning, and strategy development. Accounting also plays an essential role in economic management: the generated data of enterprises allow establishing patterns and trends in the development of industries, regions, and the economy as a whole. Accounting information has also played an important role in globalization processes, forming the foundations of sustainable economic development, the attraction of

Cite as: Zadorozhnyi, Z.-M., Ometsinska, I., \& Muravskiy, V. (2021). Determinants of Firm's Innovation: Increasing the Transparency of Financial Statements. Marketing and Management of Innovations, 2, 74-86. http://doi.org/10.21272/mmi.2021.2-06

74 
foreign capital, and the determination of innovation and investment priorities for the development of enterprises, regions, and countries. However, implementing the basic function of accounting in terms of the production of information field for the management system is accompanied by a significant number of problems related to the quality of accounting information, its ability to meet all the information needs of external and internal users. Accounting methodology and techniques often depend on many objective and subjective factors that create significant barriers to information users' communication. As an integral part of it, the accounting system and financial statements are improved to consider all economic relations elements. However, these processes often increase the communication barriers of accounting information, manifested in the misperception of its indicators due to the complicated terminological field, misunderstanding of the structure of individual accounting objects, and information overload. That leads to errors in assessing the activities of enterprises and, as a consequence, understanding the problems of economic development of the country. This situation requires research to minimize communication barriers to financial reporting as a primary source of information for management decisions.

Literature Review. The scientific literature has repeatedly raised the issue of forming accounting information that would meet the needs of its users. Scientists explore problems that create barriers in communication as accounting systems with other economic systems and the sender of accounting information (communicator) with the recipient. Thus, the scientific positioning of the accounting system as a communication basis for the information integration of stakeholders into a single information system, the operation of which is threatened by communication barriers, was initiated by us in scientific work (Zadorozhny et al., 2018). Stattler and Grabel (2020) identified communication barriers that create an obstacle to the transparency of financial statements: accounting anomalies; the rapid growth of income and/or profit; weakly visible weaknesses of internal control; noticeably «aggressive» financial actions of senior management, and the shortcomings of the personality of leaders.

In turn, Haleem and Kevin (2018) determined the competence of its users as one of the main factors influencing the accounting information system. B. Pierce and T. O'Dea pointed out the differences in the perception of accounting information by its developer and user. Besides, the researcher outlined the problems of these differences (Pierce and O'Dea, 2003). O. A. Lahovska emphasized that establishing the obstacles in accounting communications is directly proportional to the effectiveness of the enterprise management system (Lahovska, 2011). M. O. Kozlova also singled out groups of communication barriers, with an important role played by professionalism in accounting, which in turn could provoke such barriers. Besides, the researcher emphasized the need for quality language training of accountants (Kozlova, 2013). N.Viswa examined the probability of communication barriers in providing administrative services based on the questionnaires of accounting specialists from local self-government bodies and static data. The researcher explained the impact of information barriers in forming financial statements by local governments on the possibility of fraud in the use of local funds. The lack of transparency of financial statements is the non-compliance with International Financial Report Standards in statement preparation (Viswa, 2016). It stands to note that in 2009, L. V.Gheorghe explained the direct link between financial reporting transparency and compliance with IAS/IFRS (Gheorghe, 2009). The increase in the quality and transparency of financial reporting in 2020 (Figure 1) is explained by the IAS/IFRS requirements introduction by EU countries.

Report on Eurostat statistics 2020 edition on user satisfaction with the quality of the financial statements in the EU showed a growing level of informativeness and transparency of accounting information (Figure 1). Compared to 2015, in 2020, the level of satisfaction of the quality of financial statements raised from $63.40 \%$ to $80.60 \%$. And only $2.50 \%$ of stakeholders in 2020 noted a low or very low statement quality (Eurostat, 2020). Researchers from different countries are exploring the transparency of financial reporting by minimizing communication barriers with different types of accounting information users. For example, D. Wallace justified information threats in communications with 
counterparties and the possibility of their elimination through the implementation of transparency of financial statements. Furthermore, the scientist proved the existence of different options for communication barriers when interacting separately with debtors and separately with creditors, which requires the improvement of various indicators of financial reporting (Wallace, 2020).

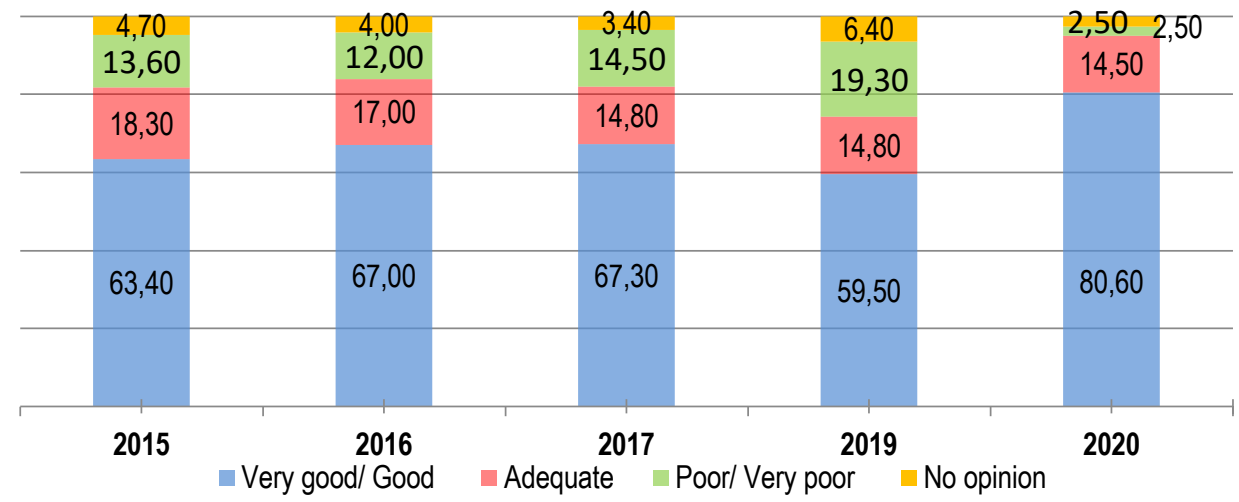

Figure 1. Stakeholders' satisfaction of transparency and informativeness of accounting and statements in EU countries

Sources: developed by the authors based on (Eurostat, 2020).

Similarly, Cendy and Khoirul (2019) explain the role of financial statements prepared under IFRS in the process of communication between enterprises and government institutions. The authors developed a method of overcoming communication noise in interaction with government agencies by increasing the transparency of reporting indicators. Lander and Auger (2008) identified the economic effect of communication barriers. Researchers have explained the relationship between economic development and financial reporting transparency.

There are also scientific studies of national features of the financial reporting transparency implementation for minimizing communication barriers: disclosure of financial statements in the Slovak Republic by explaining the impact of transparency of reporting indicators on communications with the fiscal service (Kosiciarova and Vincurova, 2015); the order of interaction of construction companies in the Russian Federation with potential buyers of real estate through financial reporting mechanisms (Rozhnova and Atazhanova, 2016); reducing corruption barriers to business development through transparent financial reporting in Iran (Mohammadi and Nezhad, 2015); Serbia's integration into the EU through transparency of accounting and financial reporting (Spasić and Denčić-Mihajlov, 2014); the impact of financial reporting transparency on oil pricing in the Persian region (Parsian et al., 2017); distinctive features in Ireland's reporting compared to the United Kingdom and the United States to ensure transparency (Moretti et al., 2017) and other. In addition, scientists explained that in different countries, there are individual characteristics of communication barriers.

The results of the analysis of the works of several Ukrainian economists, in particular Poliova and Kravtsova (2018), Tomchuk et al. ( 2016), Tyutyunnyk and Tyutyunnyk (2016), Oleksandrenko (2014), Chaika et al.(2018), Kindratska (2019), Tenytska and Hryshko (2015), Khalatur et al. (2017), Kharchenko (2015), Serebriakova and Grishchenko (2017) showed that communication barriers to financial reporting cause the formation of different values of the same indicators to assess the financial performance of the enterprise. However, researchers do not pay enough attention to ensuring the transparency of financial reporting as the main way of minimizing communication barriers, which actualizes research in this area 
and defines the article's main aim. The purpose of the article is to identify the basic communication barriers of financial reporting based on Ukrainian and foreign experience, their minimization through ensuring the transparency of accounting information, and calculation of analytical indicators.

Methodology and research methods. Theoretical and methodological ground of the research is the scientific works of Ukrainian and foreign scientists in terms of disclosing the quality of the accounting system as an information field for decision-making at various levels of management, as well as studying communication barriers that affect the quality of accounting and search ways to eliminate them. Determining the problematic issues of the quality of the accounting information system and financial information barriers was carried out through a survey of chief accountants and users of accounting information (enterprise managers and shareholders) and using the methods of theoretical generalization.

To clarify the necessity of communication barrier identification, the empirically functional methodology of cognition of economic processes was used. Scientific research is based on the principles of systemology (the science of the interdependence of systems). System scientific method is used in determining the properties of accounting as a system, improving financial statements and analysis in terms of ensuring the transparency of accounting information. Systemology allows substantiating the essence of financial reporting as a type of enterprise reporting and positioning as a channel for transmitting information to stakeholders.

The modeling method was used in the formation of the model of communication links of financial statements and the separation of channels of the interaction of its users; methods of comparison, grouping, deduction, analysis helped to establish the consequences of certain communication barriers to financial reporting and find ways to eliminate them; tabular and graphical methods - for visual presentation of research results. At the same time, the emphasis would be placed on the active use of methods of economic and mathematical analysis, extrapolation, bibliographic and bibliometric to justify the feasibility of transforming forms of financial reporting; methods of generalizations, inductions, and deductions - in forming conclusions on ensuring the transparency of accounting information reflected in the financial statements. The novelty of this research is the use of a set of scientific methods, which makes it possible to improve the taxonomy of financial reporting to minimize communication barriers.

Results. Accounting, along with controlling and evaluation functions, also performs two important information and analytical functions. The information function involves providing external and internal users with the necessary information to make management decisions. It is the basis of others because having accounting information could assess the entity's activities for management purposes, analyze the effectiveness of management decisions, monitor the safety of property, etc. Accounting information should provide the opportunity to make informed decisions by enterprise management and investors, creditors, government agencies, etc. Communication of accounting with other economic systems of the enterprise, particularly the supply department, marketing service, production units, allows to study the enterprise's information needs and form the relevant information in the system of financial and management accounting. The main role in the communication between internal and external users of accounting information is played by financial statements. It is possible to assess the investment attractiveness of the entity, innovation opportunities, creditworthiness, social responsibility and make appropriate decisions by its users. Furthermore, the use of financial reporting information leads to the formation of feedback, which contributes to the improvement of its forms and indicators. Thus, modification of information needs of the State Fiscal Service of Ukraine, the State Statistics Service of Ukraine, and other public authorities facilitates decisions on amendments to the Law of Ukraine «On Accounting and Financial Reporting in Ukraine», national provisions (standards) of accounting, which, in particular, determine the requirements for the structure of financial reporting. Similarly, appropriate adjustments could be made in connection with the globalization of the economy, the development of accounting at both national and international levels, and the actualization of doing business based on social responsibility. 
Changes in enquiries of management, investors, creditors in terms of financial statements may be manifested in the disclosure of additional items provided by the Ukrainian Accounting Standard (UAS) 1 «General requirements for financial reporting». In addition, the information requirements of the practice (internal and external users) are studied by Ukrainian and foreign scientists, who communicate them to the legislature through scientific publications. Thus, communication links that arise through the formation and use of financial statements contribute to adapting its structure to user requirements (Table 1).

Table 1. Communication channels for accounting data transmission to outside stakeholders

\begin{tabular}{|c|c|c|}
\hline № & $\begin{array}{c}\text { Type of communication } \\
\text { channel }\end{array}$ & Semantic characteristics \\
\hline 1. & $\rightarrow$ Shareholders & $\begin{array}{c}\text { Efficiency of operation, profit of the enterprise, and the number } \\
\text { of due dividends (financial statements) }\end{array}$ \\
\hline 2. & $\rightarrow$ Investors & $\begin{array}{l}\text { Economic performance and interest paid on investments } \\
\text { (financial statements) }\end{array}$ \\
\hline 3. & $\rightarrow$ Creditors & $\begin{array}{c}\text { The company's ability to repay debts and service them } \\
\text { (financial statements) }\end{array}$ \\
\hline 4. & $\rightarrow$ Other contractors & $\begin{array}{l}\text { Ability of the enterprise to fulfill its contractual obligations } \\
\text { (financial and internal reporting) }\end{array}$ \\
\hline 5. & $\rightarrow$ Fiscal service & $\begin{array}{l}\text { Reliability of accrual and timeliness of payment of taxes and } \\
\text { fees (tax reporting) }\end{array}$ \\
\hline 6. & $\rightarrow$ Statistical service & Statistical information (statistical reporting) \\
\hline 7. & $\rightarrow$ Local community & $\begin{array}{l}\text { Fulfillment of commitments made to the community regarding } \\
\text { the social development of the territory (social reporting) }\end{array}$ \\
\hline 8. & $\rightarrow$ Public institutions & $\begin{array}{l}\text { Social protection of citizens and employees of the enterprise } \\
\text { (social reporting) }\end{array}$ \\
\hline 9. & $\rightarrow$ Other entities & $\begin{array}{l}\text { Other information about the social and financial activities of the } \\
\text { company, which is used by rating agencies, charitable } \\
\text { foundations, audit and insurance companies, trade unions, etc. }\end{array}$ \\
\hline
\end{tabular}

Sources: developed by the authors.

Regardless of the type of communication channel and stakeholders, the quality of communications would be appropriate. The action of communication barriers is minimized, i.e., negative factors influencing communication processes. Pierce and O'Dea (2003) identified the main factors contributing to differences in the perception of accounting information by the developer and its user, namely as an imbalance between technical and organizational validity, functional differentiation, and inherent tension between the simultaneous requirements of independence and involvement. According to Lahovska (2011) the main obstacles to the effectiveness of accounting communications are non-compliance (violation) of the quality properties of information, including its curvature and asymmetry; selection of the inefficient type of organization of communication networks between the accounting system with other control subsystems; lack of system information links of the accounting system with other management subsystems of different hierarchical level and other structural elements of the management system; information overload in terms of employees and responsibility centers; lack of clarity of the information message generated by the accounting system in terms of content, volume and based on the need to maintain the level of confidentiality in its transmission between the elements of the management system. Kozlova (2013) identifies the following groups of communication barriers: personal (due to the individual characteristics of the sender and recipient of information); organizational (situations that reflect the shortcomings and errors in the company's management, as well as the negative impact of environmental factors); cultural (formed by traditions and norms of behavior in countries and regions, etc.); physical (obstacles created by people, objects or phenomena); language (lexical and grammatical obstacles); semantic (communication 
disorders caused by misunderstanding or insufficient understanding of the meaning of information due to the use of professional terms, phraseology, professionalism, etc.); temporal (occur due to lack of time or false confidence of the sender in the simplicity of the question). A.K. Fedenia (2006) distinguishes information asymmetry of messages, their semantic overload due to excessive availability of redundant information, the unsatisfactory structure of the enterprise among communication barriers. Haleem and Kevin (2018) note that the success of an accounting information system depends on the technical, human and conceptual skills of the user, as well as their knowledge and experience. What is the most important is that technical skills and experience have the greatest impact.

Given the above, as well as the results of a survey of chief accountants and users of accounting information (enterprises managers and shareholders), we believe that the effectiveness of communication links in the financial statements may deteriorate due to the following communication barriers:

1) unclearness ambiguity of financial reporting indicators due to different interpretations of accounting concepts, which is an important information barrier for participants in accounting communication and could lead to erroneous decisions;

2) the level of knowledge of the subjects of the communication process (communicator and recipient). This barrier could lead to the formation of poor quality accounting information (insufficient level of knowledge of the communicator) and making wrong decisions (lack of necessary knowledge of the recipient, which causes misunderstanding of accounting information and inability to operate with accounting data);

3) inaccuracy of information due to intentional (deliberate distortion of information to aim at appropriate decisions) or unintentional actions (technical errors, lack of sufficient knowledge of accounting staff). Disclosure of unreliable information in the financial statements could also be caused by noncompliance with accounting standards, particularly non-disclosure of current receivables. Notably, it is a financial asset at net realizable value. For its calculation, it is necessary to calculate the provision for doubtful debts; lack of timely revaluation of assets; depreciation of assets and liabilities, etc.;

4) lack of clarity in accounting regulations on the interpretation and structure of individual objects of accounting;

5) information oversaturation which causes a risk of ignoring important information in decisionmaking processes;

6) the presence of non-target communications, which could cause a leak of information to competitors; this barrier is eliminated for business entities that are required by law to publish financial statements;

7) the presence of informal communications. Accountants could be connected to the user of accounting information by informal connections, which could both positively (when it comes to investors, creditors, suppliers) and negatively (in the case of connections with competitors) affect the activities of the enterprise;

8) the inefficiency of the communication channel affecting the speed of obtaining accounting information and making appropriate decisions.

Several internal and external users apply financial reporting to make appropriate decisions. Communication channels with certain users of financial statements are formalized (Accounting Service State Fiscal Service of Ukraine; Accounting Service - State Statistics Service of Ukraine). Communication with other reporting users should be determined based on their information needs. Such information connections depend on the interest of the communication subjects, the enterprise's organizational structure, management style, communication networks between the accounting system with other management systems, and accounting automation. In this case, a significant role should be given to minimizing information barriers that could lead to the unreasonable interpretation of reporting indicators and making wrong decisions. 

Financial Statements

The Balance Sheet «Financial Statement» (form № 1) is the most used by external and internal users form of financial reporting. It allows calculating a significant number of enterprise indicators, solvency, independence, and business activity. A significant influence on the quality of information perception of this form of reporting for management purposes has a right understanding of its indicators. Notably, it could become a primary information barrier. Financial statements should be clear to users interested in perceiving its information and having the relevant knowledge. Indeed, if a certain legal entity or person is a user of accounting information, he/she strives to understand it.

Another situation is the availability of relevant knowledge. Not all users of financial statements have sound knowledge in the field of accounting. As a rule, most users understand the basic economic categories and their essence. Still, they cannot always give a correct interpretation of specific accounting concepts, such as «non-current assets held for sale and disposal groups», "collateral», "total income», etc. Foolowing Kozlova's (2013) opinion, «accounting terminology as words used by small groups of people who are united by the accounting profession, could act as specific communication barriers, i.e., obstacles that disrupt the transfer of accounting information and reduce its effectiveness». It emphasizes the need for a clear unification of accounting terminology with economics. It turns, it would ensure the quality of financial reporting in terms of its intelligibility and clarity.

In Ukraine, in the Balance Sheet (Financial Statement), information on assets and sources of their formation is summarized within three sections of the asset (I. Non-current assets; II. Current assets; III. Non-current assets held for sale and disposal groups) and four sections of the liabilities (I. Equity; II. Long-term liabilities and collateral; III. Current liabilities and collateral; IV. Liabilities relating to noncurrent assets held for sale and disposal groups (Ukrainian Accounting Standard 1)). In addition, the liabilities of the balance sheet provide an additional line 1800 «Net asset value of private pension fund». It is placed after the fourth section «Liabilities related to non-current assets held for sale and disposal groups», which actually means the presence of the entered fifth section.

International Accounting Standard (IAS) 1 «Presentation of Financial Statements» states that the Financial Statement should include at least items that present the following amounts: property, plant and equipment; real estate investment; non-current assets; financial assets; investments accounted for using the equity method; biological assets; stocks; trade and other receivables; cash and cash equivalents; the total amount of assets classified as held for sale and assets included in liquidation groups classified as held for sale; trade and other accounts payable; provision; financial liabilities (except for trade and other accounts payable and collateral); current tax liabilities and assets as defined in IAS 12 Income Taxes; deferred tax liabilities and deferred tax assets as defined in IAS 12; liabilities included in liquidation groups classified as held for sale in accordance with IFRS 5; uncontrolled shares represented in equity; $m$ ) issued capital and reserves relating to the owners of the parent company(IAS 1).

The items in the Ukrainian Balance Sheet (Financial Statement) are as close as possible to IAS 1 items in the Financial Statement. However, their grouping provokes discussions. Thus, the assets of the Financial Statement should be grouped according to the liquidity of assets. In Ukraine, this form of reporting items is placed in ascending order of liquidity, which led to the presentation in the first section of non-current assets, in the second - current with the appropriate grouping of items. The most liquid asset is cash and cash equivalents. Thus, the item containing information about such assets is reflected almost at the end of the asset Balance Sheet (Financial Statement) (line 1165 according to UAS 1 and paragraph "cash and cash equivalents» according to Art. 54 IAS 1). Such grouping would be understandable to a wide range of external and internal users of accounting information who are not accounting professionals. Besides, it would allow the flawless calculation of some indicators (including liquidity ratios). However, the appearance in the Ukrainian balance sheet of section III «Non-current assets held for sale and disposal groups» (line 1200), which is placed after the most liquid asset - money and their equivalents, is relatively new. This indicator is provided for in IAS 1 with a similar wording after paragraph «cash and cash 
equivalents», namely: paragraph «the total amount of assets classified as held for sale and assets included in liquidation groups classified as held for sale». It could be assumed that such grouping violates the basic principle of building a balance sheet asset and strengthens communication barriers in the financial statements, which are associated with the ambiguity of its indicators. Users interpret this section differently. Therefore, sometimes they could misunderstand the economic nature of this indicator.

Thus, Poliova and Kravtsova (2018), Tomchuk et al. (2016), Tyutyunnyk and Tyutyunnyk (2016) indicated that non-current assets held for sale and disposal groups are classified as illiquid non-current assets, most likely, focusing on the name and not on the economic essence of this indicator. Oleksandrenko (2014) referred to such assets as slow-liquid, along with stocks, prepaid expenses, other non-current assets, and, in contrast to the above scientists, consider them when calculating the current liquidity ratio. Chaika et al. (2018) didn't consider non-current assets held for sale and disposal groups in the liquidity indicators analysis. Moreover, Tenytska and Hryshko (2015), Khalatur et al. (2017), Serebriakova and Grishchenko (2017), Kontuš, and Mihanović (2019) didn't mention this type of assets in the analysis of the balance sheet and calculation of liquidity ratios. The inclusion of various components for calculating liquidity ratios leads to the inaccuracy of the results of analysis and incorrect decisions by reporting users.

A similar situation arises with the concept of «liability». Notably, this concept is used to calculate the enterprise's financial condition, including liquidity ratios, where the denominator of the formula reflects their current part. In this case, there is no clarity about the structure of liabilities in the scientific literature and Ukrainian accounting standards. Thus, in UAS 11 «Liabilities», current liabilities include current collateral. The deferred income is allocated to a separate type of liability at the level of current, long-term and contingent liabilities (Ukrainian accounting standard 11 «Liabilities»). In UAS 1, collateral is separated from current and long-term liabilities. The deferred income is included in the structure of current liabilities. UAS 11 «Liabilities» does not refer to such liabilities as liabilities related to non-current assets held for sale and disposal groups that are identified in the Ukrainian balance sheet (financial statement) in a separate section outside current and long-term liabilities. In the Ukrainian Chart of Accounts, the calculations related to non-current assets and disposal groups held for sale are reflected in sub-account 680 , which is in class 6 «Current liabilities». This situation makes it difficult for accounting professionals to understand the structure of liabilities, not to mention users of financial statements who do not know accounting standards. Based on this, the question arises, which lines of liabilities of the balance sheet (financial statement) to consider, for example, in the denominator of formulas when calculating liquidity ratios? The lack of a clear interpretation of the nature of current liabilities has led to both violations of the principle of construction of liabilities of the balance sheet and significant differences in the proposed calculations of the indicators of the enterprise's financial condition, including liquidity.

Poliova and Kravtsova (2018); Tyutyunnyk and Tyutyunnyk (2016) included liabilities related to noncurrent assets held for sale and disposal groups into fixed liabilities at the level of equity while Oleksandrenko (2014) - to long-term liabilities along with long-term liabilities and collateral. When disclosing the list of items in the Financial Statement in IAS 1 «Presentation of Financial Statements», the item «liabilities included in liquidation groups classified as held for sale» is placed directly in front of equity. As a result of that, it is possible to conclude their long-term nature. When calculating liquidity ratios, scientists usually do not mention the above type of liabilities, although there is no unity on the denominator of the formulas despite this. Kharchenko (2015), Chaika et al. (2018), Tenytska and Hryshko (2015), Serebriakova and Grishchenko (2017), Kontuš and Mihanović (2019) indicated current liabilities in the denominator of the formulas for calculating liquidity ratios, Khalatur et al., 2017 - current liabilities plus deferred income; Tyutyunnyk and Tyutyunnyk (2016) - current liabilities and collateral. Kindratska (2019) studied typical methods of calculating the solvency of the enterprise in regulations. In the study, the researcher once again confirmed the use of the generally accepted economic terms «current liabilities», 
«receivables», «current assets». Different interpretations of accounting concepts, their lack of clarity in accounting regulations, and unclear financial reporting indicators are essential information barriers for participants in accounting communication, leading to errors in assessing the enterprise's financial condition and making erroneous decisions in practice. According to the industrial enterprise (Table 2), the calculation of liquidity indicators is presented based on the components of current assets and current liabilities proposed in regulatory documents (Table 3).

Table 2. Extract from the Balance Sheet (Financial Statement) in Ukraine

\begin{tabular}{|c|c|c|c|}
\hline Asset & $\begin{array}{l}\text { Line } \\
\text { code }\end{array}$ & $\begin{array}{l}\text { At the beginning } \\
\text { of the reporting } \\
\text { period, thousand } \\
\text { UAH }\end{array}$ & $\begin{array}{l}\text { At the end of the } \\
\text { reporting period, } \\
\text { thousand UAH }\end{array}$ \\
\hline \multicolumn{4}{|l|}{ I. Non-current assets } \\
\hline in terms of non-current assets & $\ldots$ & & \\
\hline Total for section I & 1095 & 95597 & 104473 \\
\hline \multicolumn{4}{|l|}{ II. Current assets } \\
\hline Stocks & 1100 & 8512 & 5361 \\
\hline Current biological assets & 1110 & - & - \\
\hline Accounts receivable for products, goods, works, services & 1125 & 3596 & 8351 \\
\hline Accounts receivable by calculations: & 1130 & 893 & 4558 \\
\hline \multicolumn{4}{|l|}{ on issued advances } \\
\hline with a budget & 1135 & 1066 & 273 \\
\hline including income tax & 1136 & 62 & 62 \\
\hline Other current receivables & 1155 & 2625 & 1678 \\
\hline Current financial investments & 1160 & - & - \\
\hline Money and its equivalents & 1165 & 1546 & 4027 \\
\hline Deferred expenses & 1170 & 25 & 23 \\
\hline Other current assets & 1190 & 6770 & 5620 \\
\hline Total for section II & 1195 & 25033 & 29891 \\
\hline III. Non-current assets withheld for sale and disposal groups & 1200 & 6203 & 1115 \\
\hline Balance & 1300 & 126833 & 135479 \\
\hline \multicolumn{4}{|l|}{ Liabilities } \\
\hline \multicolumn{4}{|l|}{ I. Equity } \\
\hline \multicolumn{4}{|l|}{ in terms of types of equity } \\
\hline Total for section I & 1495 & 90936 & 100730 \\
\hline \multicolumn{4}{|l|}{ II. Long-term liabilities and collateral } \\
\hline \multicolumn{4}{|l|}{ in terms of types of long-term liabilities and collateral } \\
\hline Total for section II & 1595 & 4832 & 3126 \\
\hline \multicolumn{4}{|l|}{ III. Current liabilities and collateral } \\
\hline Short-term bank credits & 1600 & - & - \\
\hline \multicolumn{4}{|l|}{ Current accounts payable for: } \\
\hline long-term liabilities & 1610 & - & - \\
\hline goods, works, services & 1615 & 5167 & 4235 \\
\hline calculations with the budget & 1620 & 1335 & 1450 \\
\hline including income tax & 1621 & - & - \\
\hline insurance calculations & 1625 & 405 & 372 \\
\hline payroll calculations & 1630 & 712 & 602 \\
\hline Current accounts payable on received advances & 1635 & 1749 & 84 \\
\hline Current supplies & 1660 & 2327 & 3603 \\
\hline Deferred income & 1665 & 15619 & 12987 \\
\hline Other current commitments & 1690 & 1793 & 4392 \\
\hline Total for section III & 1695 & 29107 & 27725 \\
\hline \multicolumn{4}{|l|}{ IV. Liabilities related to non-current assets withheld for sale } \\
\hline and disposal groups & 1700 & 1958 & 3898 \\
\hline Balance & 1900 & 126833 & 135479 \\
\hline
\end{tabular}

Sources: developed by the authors. 
Z.-M., Zadorozhnyi, l., Ometsinska, V., Muravskiy. Determinants of Firm's Innovation: Increasing the Transparency of Financial Statements

Table 3. Analysis of liquidity indicators

\begin{tabular}{|c|c|c|c|c|c|c|c|c|}
\hline \multirow[t]{2}{*}{ Indicator } & \multirow{2}{*}{$\begin{array}{l}\text { Method of } \\
\text { calculation }\end{array}$} & \multirow{2}{*}{$\begin{array}{l}\text { Norm } \\
\text { ative } \\
\text { value }\end{array}$} & \multicolumn{2}{|c|}{$\begin{array}{c}\text { Estimated value based } \\
\text { on UAS rules } 11 \text { on the } \\
\text { structure of current } \\
\text { liabilities }\end{array}$} & \multicolumn{2}{|c|}{$\begin{array}{l}\text { Estimated value based on } \\
\text { the names of the sections } \\
\text { of the Balance Sheet } \\
\text { (Financial Statement) }\end{array}$} & \multicolumn{2}{|c|}{$\begin{array}{l}\text { Estimated value based } \\
\text { on the economic } \\
\text { substance of the } \\
\text { balance sheet items } \\
\text { (Financial Statement) }\end{array}$} \\
\hline & & & $\begin{array}{l}\text { At the } \\
\text { beginning } \\
\text { of the } \\
\text { period }\end{array}$ & $\begin{array}{l}\text { At the end } \\
\text { of the } \\
\text { period }\end{array}$ & $\begin{array}{l}\text { At the } \\
\text { beginning of } \\
\text { the period }\end{array}$ & $\begin{array}{l}\text { At the } \\
\text { end of } \\
\text { the } \\
\text { period }\end{array}$ & $\begin{array}{l}\text { At the } \\
\text { beginning } \\
\text { of the } \\
\text { period }\end{array}$ & $\begin{array}{l}\text { At the } \\
\text { end of } \\
\text { the } \\
\text { period }\end{array}$ \\
\hline $\begin{array}{l}\text { Current } \\
\text { liquidity ratio } \\
\text { (coverage } \\
\text { ratio) }\end{array}$ & $\mathrm{CA} / \mathrm{CL}^{1}$ & $>1$ & 1.86 & 2.03 & 0.93 & 1.23 & 0.98 & 0.98 \\
\hline $\begin{array}{c}\text { Rapid } \\
\text { liquidity ratio }\end{array}$ & $\begin{array}{c}(\mathrm{CE}+\mathrm{CFI}+\mathrm{R}) \\
/ \mathrm{CL}^{1}\end{array}$ & $\begin{array}{c}0.6- \\
0.8\end{array}$ & 0.72 & 1.28 & 0.33 & 0.78 & 0.31 & 0.60 \\
\hline $\begin{array}{c}\text { Absolute } \\
\text { liquidity ratio }\end{array}$ & $\begin{array}{c}(\mathrm{CE}+\mathrm{CFI}) / \\
\mathrm{CL}^{1}\end{array}$ & $\begin{array}{l}0.2- \\
0.3\end{array}$ & 0.11 & 0.27 & 0.05 & 0.17 & 0.05 & 0.13 \\
\hline
\end{tabular}

${ }^{1}$ Note: CA - current assets; CL - current liabilities; GZ - cash and cash equivalents; CFI - current financial investments; $R$ receivables.

Sources: developed by the authors.

Table 2 shows that the communication barriers in the financial statements might lead to erroneous values of analytical indicators. In this case, it is liquidity indicators. Thus, as noted above, the structure of current liabilities does not include deferred income in UAS 11; judging by the name of section III of the liabilities of the balance sheet, current provisions are outside the current liabilities in UAS 1. If different scientists' points of view on the composition of the accounting objects used to calculate liquidity ratios are considered, the values would be even more differentiated.Given the above, accounting standards should have clear regulations for all accounting objects, not to violate the principles of reporting, contain terminology clear as possible to all users of financial statements who are interested in the perception of relevant information. To minimize communication barriers in the Balance Sheet (Financial Statement), the assets of the financial reporting form should be divided into two sections: «Non-current assets» and «Current assets». Regarding the current section III of the balance sheet, «Non-current assets held for sale and disposal groups», it should be included in the item «inventories» of section II "Current assets». The inexpediency of separating a section for non-current assets held for sale and disposal groups, which creates significant information barriers and liabilities related to their disposal,

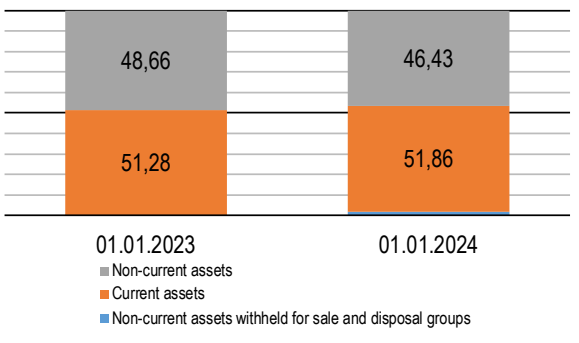

a)

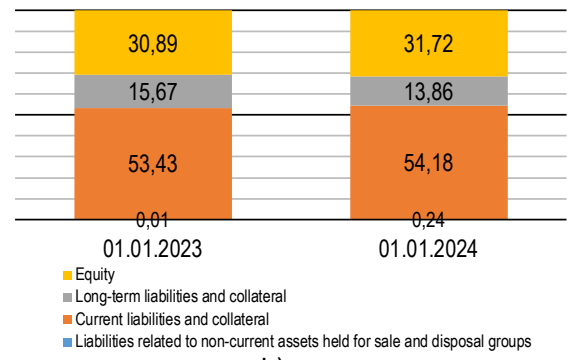

b)

Figure 2. Indicators of the Balance Sheet (Statement of Financial Position) of large and mediumsized enterprises of Ukraine as of 1 January 2019 and 4 January 12020

Sources: developed by the authors based on (SSSU, 2021). 
One of the characteristics of current assets is that they are intended for sale or use during either the operating cycle or twelve months from the balance sheet date (Ukrainian Accounting Standard 1 «General requirements for financial reporting»). Among the criteria for recognizing non-current assets and disposal groups held for sale is that their sale is expected to be completed within one year from the date they are classified as such assets. In addition, in Ukraine, for the accounting of the above assets, sub-account 286 of the same name of class 2 of the Chart of Accounts «Inventories» is assigned. As for the liabilities of the Balance Sheet (Financial Statement), it should include three sections: «Equity», «Long-term liabilities» and «Current liabilities». The current section of liabilities, «Liabilities related to non-current assets held for sale and disposal groups» should be transferred to current liabilities in a separate item. Confirmation of this position is their generalization on account 680 class 6 «Current liabilities». We believe that such construction of the Balance Sheet (Financial Statement) in Ukraine will eliminate a number of information barriers and ensure the adoption of sound management decisions based on it.

Conclusions. Accounting information summarized in the financial statements is an important tool of the management system. However, developers and users of financial statements often face communication barriers that impair the perception of accounting information and could lead to erroneous management decisions based on it. Information barriers to financial reporting, which reduce the effectiveness of communication links in the financial statements, include unclear financial reporting indicators due to different interpretations of accounting concepts; the level of knowledge of the subjects of the communication process (communicator and recipient); the inaccuracy of information due to intentional or unintentional actions; lack of clarity in accounting regulations on the interpretation and structure of individual objects of accounting; information oversaturation; availability of non-target communications; availability of informal communications; inefficiency of the communication channel. The quality of communication would be high in minimizing the impact of negative factors influencing communication processes. Based on the study, it was found that the minimization of communication barriers in the Ukrainian Financial Statement would contribute to the reflection in the asset indicators within two sections, including "Non-current assets» and "Current assets», and in liabilities - three, namely: «Equity», «Longterm liabilities» and «Current liabilities».

Further studies would examine the impact of selected information barriers to financial statements on other financial reporting forms to improve communication and the quality of accounting information.

Author Contributions. All authors contributed equally to the development of the research, the literature, data collection, research methodology and concluding sections.

Funding: This research received no external funding.

\section{References}

Cendy, M., \& Khoirul, A. (2019). An Investigation of Financial Statement Disclosure in Local Government Financial Statements. International Journal of Business and Economic Affairs, 4, 273-281. [Google Scholar]

Chaika, T. Yu., Loshakova, S. Ye., \& Vodoriz, Ya. S. (2018). Calculation of liquidity factors by the balance, accounting financial and industrial features of the enterprise in the coefficient analysis of liquidity. Economy and society, 15, 900-908. [Google Scholar]

Dementyev, V.V., \& Kwilinski, A. (2020). Institutsionalnaya sostavlyayuschaya izderzhek proizvodstva [Institutional Component of Production Costs]. Journal of Institutional Studies, 12(1), 100-116. [CrossRef]

Eurostat. (2020). Quality report on National and Regional Accounts 2020 edition. Retrieved from [Link]

Fedenia, A. K. (2006). Management: electronic educational and methodological complex. Minsk, $180 \mathrm{p}$.

Gheorghe, L. V., \& Pirnau, M. (2009). Transparency in financial statements (IAS/IFRS). European Research Studies Journal,

12, 101-108. Retrieved from [Link]

Haleem, A. H., \& Kevin, L. L. T. (2018). Impact of user competency on accounting information system success: Banking sectors in Sri Lanka. International Journal of Economics and Financial Issues, 8(6), 167. [Google Scholar] [CrossRef]

International Accounting Standard 1 «Presentation of Financial Statements». Retrieved from [Link]

Khalatur, S., Brovko, L., \& Moruga T. (2017). Methodology for assessing liquidity and solvency of agricultural enterprises. Economy and State, 12, 56-60. [Google Scholar] 
Z.-M., Zadorozhnyi, l., Ometsinska, V., Muravskiy. Determinants of Firm's Innovation: Increasing the Transparency of Financial Statements

Kharchenko, O. S. (2015). Managing solvency of the company in the system of economic security. Investments: practice and experience, 1, 55-59. [Google Scholar]

Kindratska, H. (2019). The assessment of solvency of ukrainian enterprises: problematic issues of typical methodological approaches]. Economic journal of Lesia Ukrainka Eastern European National University, 3, 133-143. [Google Scholar] [CrossRef]

Kontuš, E., \& Mihanović, D. (2019). Management of liquidity and liquid assets in small and medium-sized enterprises. Economic Research-Ekonomska Istraživanja, 32(1). [Google Scholar] [CrossRef]

Kosiciarova, S., \& Vincurova, Z. (2015). Register of financial statements as instrument of transparency in financial administration. Economic Annals-XXI, 155, 117-120. [Google Scholar]

Kozlova, M. O. (2013). The language of accounting as a practical activity - professionalism as a communication barrier. Collection of scientific works of VNAU, 1(76), 28-38. [Google Scholar]

Kwilinski, A. (2018). Mechanism of formation of industrial enterprise development strategy in the information economy. Virtual Economics, 1(1), 7-25 [CrossRef]

Lahovska, O. A. (2011). Organizational communications in the management system: accounting context. International collection of scientific article, 3(21), 222-232. [Google Scholar]

Lander, G., \& Auger, K. (2008). The Economic Impact of the Lack of Transparency in Financial Reporting. Atlantic Economic Journal, 36, 105-116. [Google Scholar] [CrossRef]

Mohammadi, S., \& Nezhad, B. M. (2015). The role of disclosure and transparency in financial reporting. International Journal of Accounting and Economics Studies, 3(1), 60-62. [Google Scholar]

Moretti, D., Nicol, S., Denis, E., \& Youngberry, T. (2019). Financial reporting in Ireland. OECD Journal on Budgeting, 19(1), 107-169. [Google Scholar] [CrossRef]

Oleksandrenko, I. V. (2014). Enterprise liquidity and solvency diagnostics. Actual Problems of Economics, 6(156), 419-426 [Google Scholar]

Parsian, H., Aghaei, M. A.б \& Kalantari, F. (2017). Relationship between Moral Intelligence, Transparency in Financial Reporting and Trust Building (In Persian). Iranian 15th National Conference on Accounting, Tarbiat Modares University, May 25-26th, 2017. Retrieved from [Link]

Pierce, B., \& O'Dea, T. (2003). Management accounting information and the needs of managers: Perceptions of managers and accountants compared. The British Accounting Review, 35(3), 257-290. [Google Scholar] [CrossRef]

Poliova, T. V., \& Kravtsova, Y. V. (2018). Analysis of liquidity of the enterprise by example PJSC «BONDARIVSKE». Effective economics: electronic scientific professional publication, 10. [Google Scholar] [CrossRef]

Rozhnova, O., \& Atazhanova, D. (2016). Methodological aspects transparency financial statements of construction companies. Proceedings of the Voronezh State University of Engineering Technologies, 4, 386-390. [CrossRef]

Serebriakova, N. A., \& Grishchenko, N. V. (2017). Improving liquidity and solvency management of an enterprise. Bulletin of the Voronezh State University of Engineering Technologies, 79(2), 346-353.

Spasić, D., \& Denčić-Mihajlov, K. (2014). Transparency of financial reporting in Serbia-Regulatory framework and reporting practices. Procedia Economics and Finance, 9, 153-162. [Google Scholar] [CrossRef]

SSSU. (2021). Indicators of the balance of large and medium-sized enterprises by type of economic activity. Retrieved from [Link]

Stattler, E., \& Grabel, J. A. (2020). Financial statement fraud. The Master Guide to Controllers' Best Practices, Second Edition, 445-448. [CrossRef]

Tenytska, N. B., \& Hryshko, Yu. S. (2015). Theoretical aspects of assessment of solvency of the enterprise in modern conditions. Global and national economic problem, 5, 372-376. [Google Scholar]

Tomchuk, O. F., Fabiianska, V. Yu., \& Dovhopoliuk H. O. (2016). An estimation of liquidity and solvency is in the context of the financial state of enterpise. Eastern Europe: Economics, Business and Management, 5(5), 345-351. [Google Scholar]

Tyutyunnyk, Y. M., \& Tyutyunnyk, S. V. (2016). Mechanism of factor analysis of financial performance indicators across industries. Actual problems of economics, 5(179), 421-429. [Google Scholar]

Ukrainian Accounting Standard 1 «General requirements for financial reporting» by order of the Ministry of Finance of Ukraine, 07.02.2013. № 73. Retrieved from [Link]

Ukrainian accounting standard 11 «Liabilities» by order of the Ministry of Finance of Ukraine 31.01.2000. № 20. Retrieved from [Link]

Viswa, N. (2016). Assessment of Enhancing Transparency of Financial Statements. International Journal of Accounting and Financial Reporting, 6, 175. [CrossRef]

Wallace, D. (2020). Users of Financial Statements. Financial Statement Analysis: Basis for Management Advice, 7, 71-78. [CrossRef]

Zadorozhnyi, Z. M. V., Muravskyi, V. V., Shevchuk, O. A., \& Sudyn, Y. A. (2018). Management accounting of the settlements with contractors in innovative environment of business communications. Marketing and Management of Innovations, 2, 103-112. [Google Scholar] [CrossRef] 
Z.-M., Zadorozhnyi, l., Ometsinska, V., Muravskiy. Determinants of Firm's Innovation: Increasing the Transparency of Financial Statements

\begin{abstract}
Зеновій-Михайло Задорожний, д.е.н, професор, Західноукраїнський національний університет, Україна
Ірина Омецінська, к.е.н., доцент, Західноукраїнський національний університет, Україна

Володимир Муравський, д.е.н., професор, Західноукраїнський національний університет, Україна

Детермінанти інноваційного розвитку фірми: підвищення траспарентності фінансової звітності

Фінансова звітність підприємств в умовах глобалізації та цифровізації економіки є комунікаційним каналом передачі облікової інформації до стейкхолдерів. Автори наголошено, що комунікаційні бар'єри загрожують повному та ефективному сприйняттю облікових даних користувачами, що може призводити до прийняття хибних управлінських рішень. Для мінімізації негативного впливу комунікаційних загроз необхідним $€$ удосконалення фінансової звітності систем обліку за допомогою механізмів зворотних комунікацій. Метою статті $€$ висвітлення основних комунікаційних бар'єрів фінансової звітності на основі аналізу досвіду України та інших країн. У рамках даного дослідження, автори довели наслідки дії низки комунікаційних бар'єрів на прикладі розрахунку показників ліквідності з подальшим пошуком шляхів мінімізації негативного впливу. У статті виокремлено основні комунікаційні бар'єри сприйняття облікової інформації, такі як: незрозумілість показників фінансової звітності у зв'язку з різним тлумаченням облікових понять; неналежний рівень знань суб'єктів комунікаційного процесу (комунікатора і реципієнта); неправдивість інформації, зумовлена зумисними або незумисними діями; відсутність чіткості в облікових нормативних документах щодо трактування і структури окремих об'єктів обліку; інформаційне перевантаження; наявність нецільових та неформальних комунікацій; неефективність комунікаційного каналу. Авторами обґрунтовано вплив комунікаційних загроз у системі обліку на прикладі формування української форми фінансової звітності Баланс (Звіт про фінансові результати). За результатами дослідження запропоновано трансформувати форму фінансової звітності Баланс (Звіт про фінансові результати) в Україні через виокремлення двох розділів в активі («Необоротні активи» та «Оборотні активи») і трьох в пасиві («Власний капітал», «Довгострокові зобов'язання» та «Поточні зобов'язання») з метою оптимізації аналізу показників фінансового стану. Автори наголосили, що це сприятиме ефективному сприйняттю обліково-аналітичних даних стейкхолдерами. При цьому критерій мінімізації впливу комунікаційних ризиків доцільно використовувати при трансформації інших форм фінансової та інтегрованої звітності. Розроблені пропозиції будуть корисними при реформуванні фінансової звітності в інших країнах для забезпечення транспарентності та максимізації сприйняття облікової інформації.

Ключові слова: фрінансова звітність, комунікаційні бар'єри, комунікаційні зв'язки, користувачі інформації, прозорість фінансової звітності, баланс (звіт про фінансовий стан), показники ліквідності.
\end{abstract}

